\title{
DAMPAK MENGGUNAKAN GAME ONLINE TERHADAP KREATIVITAS BERPIKIR
}

\author{
Robino Indan, Harri Kurniawan \\ Universitas Putra Indonesia YPTK, Padang \\ Email: Robino@upiyptk.ac.id
}

\begin{abstract}
Abstrak
Game online pada saat sekarang ini bukan hanya sekedar pengisi waktu luang tetapi sudah masuk kategori kebutuhan, seiring perkembangan teknologi dan mudahnya mendapatkan akses internet membuat game online menjadi sebuah hiburan yang wajib dimiliki oleh Mahasiswa - Mahasiswa, remaja bahkan orang tua. Pemikiran kebanyakan orang game online mepunyai dampak negatif, kecanduan game online bisa membuat seseorang menjadi antipati terhadap lingkungan sekitar yang sebenarnya, Tetapi dibalik dampak negatif terdapat beberapa dampak positif yang dihasilkan oleh game online yaitu para pemain akan mendapatkan cara berfikir yang cepat dan kreatif yang bisa didapat dari game strategi, tidak hanya itu pemain juga bisa belajar team work dari sebuah permainan game. Para pemain game online bisa memanfaatkan hobi tersebut untuk membuka peluang usaha seperti youtube, jual beli aset di karakter game online, sampai membuat game online sendiri. Teknik pengumpulan sampel pada penelitian ini memakai metode korelasional, jumlah sample yang di teliti 45 orang yang tediri dari $82 \%$ laki - laki dan 18\% perempuan dangan usia $40 \%$ di bawah 20 tahun dan $60 \%$ diatas 20 Tahun. Dengan analisa data menggunakan metode Servqual di dapatkan hasil Game Online dapat meningkatkan pikiran kreatif yang berdampak pada kreatifitas dalam berwirausaha.
\end{abstract}

Kata Kunci: Game_Online; Servqual; Berfikir_Kreatif; Wirausaha;

\begin{abstract}
Abstrak
Online games at this time are not just free time fillers but have entered the category of necessity, along with technological developments and easy access to the internet making online games an entertainment that must be owned by students, teenagers, and even parents. The thinking of most people online games has a negative impact, online game addiction can make someone antipathy to the real environment, but behind the negative impact, there are several positive impacts generated by online games, namely players will get fast and creative ways of thinking that can be obtained. from strategy games, not only that players can also learn teamwork from gameplay. Online game players can take advantage of this hobby to open business opportunities such as YouTube, buying and selling assets in online game characters, to making their own online games. The sample collection technique in this study used a correlational method, the number of samples studied was 45 people consisting of $82 \%$ male and $18 \%$ female with the age of $40 \%$ under 20 years and $60 \%$ over 20 years. By analyzing the data using the Servqual method, the results of online games can increase creative thinking which has an impact on creativity in entrepreneurship.
\end{abstract}

Keywords: Game_Online; Servqual; Thinking Creative; Entrepreneur;

\section{PENDAHULUAN}

Perkembangan teknologi saat ini sangat cepat. Hingga para ahli menyebutnya dengan gejala revolusi. Teknologi sekarang ini semakin efektif dan efisien untuk saling 
berkomunikasi, khususnya komunikasi jarak jauh. Salah satu perkembangan teknologi tersebut adalah internet. Internet merupakan salah satu bagian komunikasi yang memiliki peranan besar dalam menyampaikan informasi yang dibutuhkan masyarakat. Kebutuhan berita dan informasi membuat internet seringkali menjadi pilihan utama masyarakat untuk memenuhi kebutuhan informasi. Hal ini dikarenakan internet dianggap lebih up to date dibandingkan dengan media surat kabar dan televisi. Selain untuk mencukupi kebutuhan informasi internet juga sering digunakan untuk hiburan. Salah satu contohnya adalah game online. Game merupakan salah satu industri besar di dunia saat ini. Perkembangan game begitu pesat dengan jenis yang beragam, mulai game yang hanya dapat dimainkan oleh satu orang saja hingga game yang dapat dimainkan oleh beberapa orang sekaligus (Putra \& Muslim, 2013), perkembangan game juga menyasar pada pengguna computer dengan jaringan internet. Hal ini sering disebut dengan istilah game online. Game online adalah sebuah permainan (games) yang dimainkan di dalam suatu jaringan komputer ( kurniawan teguh martono, 2015 ). Game online merupakan salah satu hal yang digemari sebagai sarana hiburan dan bahkan sudah menjadi sebuah cabang olah raga yang kita kenal dengan sebutan e sport. Hal ini dikarenakan game bagi kebanyakan orang merupakan sarana hiburan yang menyenangkan. Melalui game mereka bisa melupakan sejenak kejadian-kejadian yang terjadi di kampus, kantor ataupun sekolah. Semakin berkembangnya teknologi membuat game online semakin marak dan tentunya ini merupakan kebahagiaan tersendiri bagi para gamers.

Game online saat ini berbeda dengan game online yang diperkenalkan untuk pertama kalinya. Pada saat muncul perdana tahun 1960, Pada saat komputer hanya bisa dipakai 2 orang saja untuk bermain game. Lalu muncul komputer dengan kemampuan time-sharing sehingga pemain yang memainkan game tersebut bisa lebih banyak dan tidak harus berada di suatu ruangan yang sama (multiplayer game). Game online merupakan fenomena baru di Asia tenggara, namun memiliki banyak peminat, terutama di Indonesia. Game online di Indonesia terutama di kota-kota besar, game sangat digemari, dan para pemain game terutama remaja dapat berjam-jam duduk di depan komputer. Selain itu, bermain game online dilakukan oleh remaja dengan motif yang bervariasi, mulai sebagai media hiburan hingga menjadi pekerjaan seperti youtube. Selama ini game online cenderung dianggap negatif karena banyaknya Mahasiswa yang bolos sekolah serta sedikitnya sosialisasi dan berinteraksi langsung dengan lingkungan sekitar akibat bermain game online secara berlebihan. Masyarakat banyak menilai dari sisi negatif tanpa melihat sisi positif dari game online. Game online juga memiliki sisi positif. Game online dapat melatih otak untuk terbiasa berpikir kreatif. Pemain game online juga dilatih untuk terbiasa berpikir cepat mencari solusi yang terbaik pada saat terdesak. Bermain game online juga dapat melatih teamwork yang pastinya akan dibutuhkan pada saat Mahasiswa memasuki dunia bekerja. Bermain game online juga dapat melatih kegigihan ataupun kemauan keras dari pemain game online tersebut. Salah satu cara untuk melatih berpikir kreatif yaitu dengan bermain game online. Di dalam sebuah game online biasanya terdapat masalah ataupun teka-teki untuk dipecahkan. Oleh karena itu diperlukan kreativitas, untuk menciptakan kreativitas maka dituntut berpikir kreatif agar dapat memecahkan masalah ataupun teka-teki di dalam game online tersebut.

Model kualitas jasa SERVQUAL (singkatan dari Service Quality dikembagkan oleh (Parasuraman \& Berry, 1985), dalam serangkaian penelitian mereka terhadap enam sektor jasa, yaitu: reparasi peralatan rumah tangga, kartu kredit, asuransi, sumbangan telepon interlokal, perbangkan ritel, dan pialang sekuritas. SERVQUAL ini 
dikenal pula dengan GAP Analysis model. SERVQUAL ini dikembangkan dengan maksud untuk membentu para manajer dalam menganalisis sumber masalah kualitas dan memahami cara-cara memperbaiki kualitas jasa. Metode ini dikembangkan (Aggy Pramana, 2020)

Metode servqual diyakini sangat fleksibel dan memiliki toleransi terhadap data-data yang ada. Dengan menggunakan metode servqual akan dihasilkan suatu analisa yang mampu mengetahui tingkat produktifitas mahasiswa pecandu game online terhadap kreativitas berwirausaha. Berdasarkan latar belakang di atas, maka penelitian ini akan mengkaji lebih lanjut tentang Analisis pengaruh mahasiswa pemain game online terhadap intensi Berfikir Kretif dengan metode servqual di Sumatra Barat.

\section{METODE PENELITIAN}

Metode penelitian yang digunakan adalah metode korelasional. Menurut Arikunto (2006: 247), penelitian korelasional merupakan penelitian yang dimaksudkan untuk mengetahui ada tidaknya hubungan antara dua atau beberapa variabel.

\section{Populasi}

Populasi dalam penelitian ini adalah seluruh Mahasiswa yang tinggal di Kelurahan Lubuk Begalung yang beruasia 19 - 27 tahun yang berjumlah 664 orang. Hasil observasi jumlah Mahasiswa yang gemar barmain game online sebanyak 200 orang. Mahasiswa yang menjadi fokus penelitian ini adalah Mahasiswa yang sering menggunakan game online di beberapa warung internet di lingkungan kelurahan Lubuk Begalung.

\section{Sampel}

Sampel pada penelitian ini adalah $20 \%$ dari populasi hasil observasi jumlah Mahasiswa yang gemar bermain game online. Penarikan sampel menggunakan Random Sampling (acak sederhana) sehingga diperoleh sampel sebanyak 45 responden. Penggunaan teknik ini memungkinkan untuk memberi peluang kepada populasi yang lebih kecil untuk tetap dipilih sebagai sampel (Rakhmat, 2004: 79)

\section{Teknik Pengumpulan Data}

Menurut Sugiyono (2007: 57), “Teknik pengumpulan data adalah merupakan langkah yang paling strategis dalam penelitian, karena tujuan dari penelitian adalah mendapatkan data. Tanpa mengetahui teknik pengumpulan data, maka peneliti tidak akan mendapatkan data yang memenuhi standar yang ditetapkan". Adapun teknik pengumpulan data pada penelitian ini adalah: A. Kuesioner, yaitu suatu pengumpulan data dengan cara memberikan angket tertutup kepada responden. Pembagian kuesioner kepada responden didukung pula dengan wawancara dengan masyarakat yang dijadikan responden dengan pertimbangan agar data kuesioner yang diberikan benarbenar terjawab dengan baik, sehingga memudahkan masyarakat dalam memberikan/mengisi kuesioner tersebut. B. Pengamatan (observation), yaitu dilakukan untuk melihat, mengamati dan mengevaluasi secara langsung obyek penelitian.

\section{Teknik Analisis Data}

Analisis data adalah proses penyederhanaan data ke dalam bentuk yang lebih mudah dibaca atau diinterpretasikan (Singarimbun, 1995: 263). Teknik analisis data yang digunakan dalam penelitian ini adalah teknik perhitungan statistik deskriptif kuantitatif dengan alat analisis regresi linear sederhana. Analisis regresi sederhana yaitu untuk menentukan hubungan antara dua variabel dan memperkirakan variabel tidak bebas $\mathrm{Y}$ berdasarkan variabel bebas $\mathrm{X}$ dinyatakan dengan persamaan garis lurus. Bentuk dari persamaan regresi adalah sebagai berikut:

$\mathbf{Y}^{\prime}=\mathbf{a}+\mathbf{b X}$

Keterangan:

$\mathrm{Y}^{\prime}=$ Variabel dependen (nilai yang diprediksikan) 


$$
\begin{aligned}
& \mathrm{X}=\text { Variabel independen } \\
& \mathrm{a}=\text { Konstanta (nilai } \mathrm{Y}^{\prime} \text { apabila } \mathrm{X}=0 \text { ) } \\
& \mathrm{b}=\text { Koefisien regresi (nilai peningkatan } \\
& \text { ataupun penurunan) }
\end{aligned}
$$

\section{Pengujian Validitas dan Reliabilitas}

Untuk mendapatkan data yang valid, maka sebelum kuesioner dibagikan kepada responden dilakukan uji terhadap validitas dan reliabilitas. Validitas suatu tes menunjukan seberapa baik alat tes dapat mengukur apa yang seharusnya diukur, sedangkan reliabilitas alat ukur menunjukan seberapa konsisten hasil pengukuran yang dilakukan pada waktu yang berlainan (Sugiyono, 2007: 50). Rumus yang digunakan adalah rumus Alfa Cronbach, karena rumus ini digunakan pada item yang skornya lebih dari 1 seperti pada skala Likert. Adapun rumusnya dapat dilihat sebagai berikut:

$$
\alpha=\left(\frac{K}{K-1}\right)\left(\frac{s_{r}^{2}-\Sigma s_{i}^{2}}{s_{x}^{2}}\right)
$$

Keterangan:

$=$ koefisien reliabilitas Alpha Cronbach

$K=$ jumlah item pertanyaan yang diuji

$s i^{2}=$ jumlah varians skor item

$S X^{2}=$ Varians skor-skor tes (seluruh item

$\mathrm{K})$

\section{HASIL PENELITIAN}

\section{Uji Hipotesis}

Uji hipotesis yaitu pengujian data secara statistik untuk mengetahui apakah data hipotesis dalam penelitian dapat diterima atau ditolak. Pengujian hipotesis pada penelitian ini adalah sebagai berikut:

H0: Tidak ada efek positif dan signifikan antara game online terhadap kreativitas berpikir Mahasiswa.

H1: Ada efek positif dan signifikan antara game online terhadap kreativitas berpikir Mahasiswa.

Uji $t$ untuk mengetahui tingkat keberartian masing-masing variabel game online (X) terhadap kreativitas berpikir Mahasiswa (Y) maka, digunakan Uji t, dengan kriteria pengujian : jika Sig $\mathrm{t}<\alpha$ 0,05 atau thitung $>$ tabel ini berarti terdapat efek yang positif dan signifikan antara Game Online (X) terhadap Kreativitas Berpikir Mahasiswa (Y) di Kelurahan Lubug Begalung.

Hasil analisis regresi linear sederhana menunjukkan bahwa variabel game online yang meliputi game online $P U B G$ dan game online clash of clans mempunyai nilai Sig t sebesar 000, jika dibandingkan dengan taraf signifikan 0,05 maka nilai Sig t $000<\alpha=0,05$ atau 5\%. Hal ini dapat diartikan bahwa hipotesis penelitian (H1) yang diajukan terbukti atau dapat diterima bahwa terdapat efek positif dan signifikan antara game online dengan kreativitas berpikir Mahasiswa di Kelurahan Lubug Begalung atau dengan kata lain jika nilai thitung $>$ tabel maka, $\mathrm{H}_{0}$ ditolak dan $\mathrm{H}_{1}$ diterima, dimana thitung sebesar 16,368 sedangkan ttabel sebesar 1,686 sehingga dapat diambil keputusan $\mathrm{H} 0$ ditolak dan H1 diterima. Sehingga dapat disimpulkan bahwa game online memiliki efek positif dan signifikan terhadap kreativitas berpikir Mahasiswa di Kelurahan Lubug Begalung. Rincian data dari 45 resonden terdiri dari $82 \%$ Berjenis kelamin lelaki dan $18 \%$ perempuan serta umur responden berkisar $40 \%$ di bawah 20 tahun dan $60 \%$ di atas 20 tahun.

Selanjutnya akan di lakukan perbandingan GAP 5 persepsi dan harapan, Tingkat persepsi yang dirasakan oleh koresponden dan tingkat harapan yang harapkan oleh koresponden harusnya di imbangi agar tingkat kreatifitas semakin tinggi dan produktifitas di era modren punbisa di dapatkan, Terlihat dari Gambar 1. ternyata kenyataan masih dibawah dari tingkat kebutuhan 


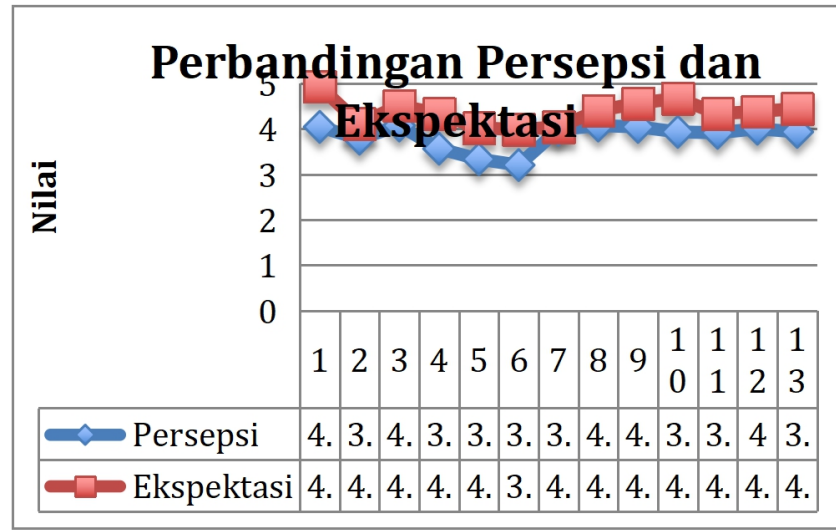

Gambar 1 : Perbandingan Persepsi dan Harapan

\section{PEMBAHASAN}

Berdasarkan hasil analisis dalam penelitian ini, diperoleh koefisien regresi yang menunjukkan efek game online terhadap kreativitas berpikir Mahasiswa di Kelurahan Lubug Begalung Kota Padang yang bertanda positif. Dalam hal ini peneliti menghubungkan beberapa jawaban dari variabel bebas dan variabel terikat. Dapat disimpulkan dari variabel pertama yang dihubungkan bahwa semakin sering Mahasiswa bermain game online maka semakin bertambah kemampuan kognitifnya, yaitu dimana dengan bermain game online dapat melatih kemampuan berbahasa inggris Mahasiswa ini dikarenakan kebanyakan alur cerita yang di ceritakan dalam game online menggunakan bahasa inggris. Kemampuan kognitif dapat diasah dengan berbagai cara, salah satunya dengan bermain game. Bermain game secara tidak berlebihan dapat menambah kemampuan kognitif dari pemain. Game online dalam hal ini menjadi stimulus untuk merangsang Mahasiswa yang merupakan cara agar kemampuan kognitif bertambah sebagai responnya. Mahasiswa menyatakan bahwa setelah mengenal game online kecerdasan mereka bertambah serta mereka memperoleh ideide/gagasan baru untuk memecahkan masalah setelah menggunakan game online. Hal ini menunjukkan kalau game merupakan salah satu cara yang efektif untuk meningkatkan kemampuan kognitif bila tidak dikonsumsi secara berlebihan. Variabel kedua menghubungkan antara keseringan bermain game online dengan sikap lebih terbuka. Game online dalam hal ini menjadi stimulus untuk merangsang Mahasiswa yang merupakan cara agar mempunyai sikap lebih terbuka sebagai responnya. Mahasiswa menyatakan bahwa semakin sering bermain game online maka mereka menjadi lebih terbuka dengan halhal baru. Selain untuk menambah kemampuan kognitif game juga dapat membuat Mahasiswa mempunyai sikap yang lebih terbuka dengan hal-hal baru. Game menjadi stimulus kepada Mahasiswa agar mempunyai sikap yang lebih terbuka dengan hal-hal baru. Sikap yang lebih terbuka disini maksudnya Mahasiswa mau menerima dan mencoba hal-hal yang belum pernah dirasakan sebelumnya. Sehingga dengan sikap yang lebih terbuka tersebut Mahasiswa mampu mempersiapkan dirinya untuk menerima stimuli internal maupun eksternal. Sikap yang terbuka akan membuat Mahasiswa memiliki minat yang beragam dan luas serta memiliki pengalaman yang lebih dari orang lain.

Variabel ketiga menghubungkan antara keseringan bermain game online dengan sikap yang bebas. Game online dalam hal ini menjadi stimulus untuk merangsang Mahasiswa yang merupakan cara agar mempunyai sikap yang bebas sebagai responnya. Mahasiswa menyatakan bahwa semakin sering bermain game online maka mereka semakin kreatif. Semakin kreatif berarti semakin pantang menyerah, semakin berpikir beda dari biasanya dan semakin unik. Game merangsang Mahasiswa untuk dapat bertindak lebih kreatif. Tidak mudah menyerah ketika menghadapi suatu masalah dan mencari solusi yang tepat merupakan bentuk kreativitas. Orang kreatif memandang masalah dari sisi positif, karena dengan cara seperti itu mereka tidak akan mudah 
menyerah dan memiliki solusi untuk menyelesaikannya. Serta bermain game online dapat meningkatkan rasa percaya diri. Bermain game dapat menambah rasa percaya diri Mahasiswa. Game menstimulus Mahasiswa agar rasa percaya dirinya meningkat. Percaya diri berarti yakin terhadap kemampuan yang dimiliki untuk menyelesaikan masalah yang datang. Dengan rasa percaya diri yang tinggi kita dapat mengeluarkan semua potensi yang ada dalam diri kita.

Berdasarkan hasil analisis linear sederhana untuk variabel game online terhadap kreativitas berpikir Mahasiswa di Kelurahan Lubug Begalung Kota Padang, game online sangat berpengaruh signifikan terhadap kreativitas berpikir Mahasiswa di Kelurahan Lubug Begalung Kota Padang, menunjukan nilai koefisien determinasi sebesar 0,876 dapat diartikan bahwa sebesar $87,60 \%$ ditentukan oleh variabel (X) dan yang lain di pengaruhi oleh variabel lain diluar penelitian.

\section{KESIMPULAN DAN SARAN}

\section{Kesimpulan}

Berdasarkan hasil analisis dan pembahasan mengenai efek game online (X) Terhadap Kreativitas Berpikir Mahasiswa (Y) di Kelurahan Lubug Begalung Kota Padang dengan menggunakan alat analisis SERVQUAL, menunjukkan bahwa game online dalam hal ini yaitu game online $P U B G$ dan game online clash of clans berpengaruh terhadap kreativitas berpikir Mahasiswa.

Besarnya pengaruh tersebut dapat diliat pada nilai koefisiensi determinasi $\left(\mathrm{r}^{2}\right)=$ 0,876 . Hal tersebut berarti bahwa $87,60 \%$ dijelaskan oleh variabel kreativitas berpikir Mahasiswa dipengaruhi oleh variabel game online, sisanya 12,400\% dipengaruhi oleh variabel lain diluar model. Sehingga dapat ditarik kesimpulan bahwa pengaruh variabel bebas terhadap variabel terikat pengaruhnya sangat kuat.
Hal ini dibuktikan dengan nilai thitung lebih besar dari nilai ttabel, dengan demikian maka hipotesis dalam penelitian ini dapat diterima

\section{Saran}

Berdasarkan kesimpulan yang diperoleh, maka dapat diajukan saran atau rekomendasi sebagai berikut:

1. Penelitian yang dilakukan peneliti diharapkan dapat memberikan informasi kepada pemain game online tentang manfaat dari sisi berpikir kreatif. Penelitian ini menyimpulkan bahwa terdapat efek antara game online dengan kreativitas berpikir Mahasiswa, berarti bermain game online tidak buruk, asalkan tidak melalaikan kewajiban- kewajiban yang harus diselesaikan terlebih dahulu. Hendaknya pihak pengelola bekerja sama dengan orang tua agar tidak memperbolehkan pelajar masuk pada jam sekolah, sehingga tingkat pembolosan dapat diminimalisir. Dengan demikian pelajar akan terbiasa untuk melaksanakan kewajiban dahulu sehingga kebiasaan tersebut akan terbawa sampai ke jenjang yang lebih tinggi.

2. Penelitian ini diharapkan mampu menambah ilmu terutama di bidang Sosial

Penelitian ini memberi kita contoh bahwa ilmu juga bisa didapatkan dengan cara bermain. Secara sadar atau tidak, pembelajaran melalui permainan akan terasa lebih menarik. Selain dapat menikmati hobi, player/pemain juga akan mendapatkan efek dari permainan tersebut. Dalam hal ini peneliti meneliti tentang efek game online terhadap kreativitas berpikir Mahasiswa. Peneliti berharap penelitian ini dapat menambah referensi ilmu terutama di bidang 
sosial.

3. Game online memang menarik untuk itu, hendaknya perlu dilakukan berbagai gebrakan yang inovatif dari pihak pengembang atau perusahaan game tersebut agar game online tetap eksis. Selain itu, game online mengasah kemampuan berpikir karena dibutuhkan kecerdikan untuk mengalahkan lawan, di satu sisi game online dapat mempengaruhi sisi emosional player/pemain ketika sudah merasa kecanduan dan akan memberikan kepuasan tersendiri bila kemenangan dicapai.

4. Sebagai bahan referansi bagi peneliti selanjutnya, utuk memperoleh penjelasan yang lebih komprehensif tentang efek game online terhadap kreativitas berpikir Mahasiswa, maka dalam penelitian berikutnya disarankan agar dapat mengembangkan dimensi variabel yang lain maupun memperluas objek yang diteliti.

\section{UCAPAN TERIMA KASIH}

Terima kasih kepada Dipa Direktorat Riset Dan Pengabdian Masyarakat, Direktorat Jedral Penguat Riset Pengembangan, Teknologi dan Pendidikan Tinggi

\section{DAFTAR PUSTAKA}

Costikyan, g. (2004). I have no words \& i must design: toward a critical vocabulary for games. Retrieved from

http://www.digra.org/wpcontent/ uploads/digital-library/05164.51146.pdf

Crawford, c. (2003). Chris crawford on game design. Peachpit

Putra, y. S., \& muslim, m. A. (2013). Game chicken roll dengan menggunakan metode forward chaining. Jurnal eeccis,
$7(1), 41-46$.

Harto, B. (2015). Analisis tingkat kepuasan pelanggan dengan pendekatan fuzzy servqual dalam upaya peningkatan kualitas pelayanan (studi kasus di bengkel resmi bajaj padang). Jurnal TeknoIf, 3(1).

Bakhtiar, A., Susanty, A., \& Massay, F. (2010). Analisis kualitas pelayanan yang berpengaruh terhadap kepuasan pelanggan menggunakan metode servqual dan model kano (studi kasus:

PT. PLN UPJ Semarang Selatan).J@ti Undip: Jurnal Teknik Industri, 5(2), $77-$ 84.

Aisyati, A., Rochman, T., \& Rahmadi, H. (2009). Analisa Kualitas Pelayanan Rumah Sakit Umum Daerah (RSUD) Wonogiri Menggunakan Metode Fuzzy-SERVQUAL. GEMA TEKNIK Majalah Ilmiah Teknik, 10(2), 22-26. Teguh Martono, K. (2015). Pengembangan Game Dengan Menggunakan Game Engine Game Maker. Jurnal Sistem Komputer, 5(1), 23-30.

Anisa, N., Asrosi, A., \& Wicaksono, L. PENGARUH KEBIASAAN BERMAIN GAME ON LINE TERHADAP KREATIVITAS BELAJAR KELAS VIII SMP MUHAMMADIYAH 1 PONTIANAK. Jurnal Pendidikan dan Pembelajaran, 7(9).

Andika, M., \& Madjid, I. (2012). Analisis Pengaruh Sikap, Norma Subyektif dan Efikasi Diri Terhadap Intensi Berwirausaha Pada mahasiswa Fakultas Ekonomi Universitas Syiah 
Kuala. In Eco-Entrepreneurship

Seminar \& Call for Paper" Improving

Performance by Improving

Environment (pp. 190-196).

Aprilianty, E. (2012). Pengaruh kepribadian

wirausaha, pengetahuan

kewirausahaan, dan lingkungan

terhadap minat berwirausaha siswa

SMK. Jurnal Pendidikan Vokasi, 2(3).

Gusman, A. P., Andrianof, H., \& Selfira, S.

(2020). VISITOR SATISFACTION

ANALYSIS OF CREATIVE INDUSTRY IN

TOURISM LOCATIONS USING

SERVQUAL METHOD. Jurnal Ipteks

Terapan, 14(3), 285-291. 